\title{
Social Media its Impact with Positive and Negative Aspects
}

\author{
Shabnoor Siddiqui \\ Mats University \\ Raipur (C.G.), India
}

\author{
Tajinder Singh \\ Mats University \\ Raipur (C.G.), India
}

\begin{abstract}
Social media is a platform for people to discuss their issues and opinions. Before knowing the aspects of social media people must have to know what is social media? Social media are computer tools that allows people to share or exchange information's, ideas, images, videos and even more with each other through a particular network. In this paper we cover all aspects of social media with its positive and negative effect. Focus is on the particular field like business, education, society and youth. During this paper we describe how these media will affect society in a broad way.
\end{abstract}

Keywords: social media, business, society, youngsters, education.

\section{INTRODUCTION}

Now a day's social media has been the important part of one's life from shopping to electronic mails, education and business tool. Social media plays a vital role in transforming people's life style. Social media includes social networking sites and blogs where people can easily connect with each other. Since the emergence of these social networking sites like Twitter and Facebook as key tools for news, journalists and their organizations have performed a high-wire act [1]. These sites have become a day to day routine for the people. Social media has been mainly defined to refer to "the many relatively inexpensive and widely accessible electronic tools that facilitate anyone to publish and access information, collaborate on a common effort, or build relationship" [2].

\section{IMPACT OF SOCIAL MEDIA ON VARIOUS FIELDS \\ 1.1 Impact of Social Media on Education}

As per the survey of previous research, $90 \%$ of college students use social networks. Technology has shown a rapid development by introducing small communication devices and we can use these small communication devices for accessing social networks any time anywhere, as these gadgets include pocket computers, laptops, iPads and even simple mobile phones (which support internet) etc.[5].For the purpose of education social media has been used as an innovative way. Students should be taught to use this tool in a better way, in the educational classes' media just being used for messaging or texting rather than they should learn to figure out how to use these media for good [3]. Social media has increased the quality and rate of collaboration for students. With the help of social media students can easily communicate or share information quickly with each through various social sites like Facebook, Orkut, and Instagram etc. [4]. It is also important for students to do some practical work instead of doing paper work. They can also write blogs for
Teachers as well as for themselves to enhance their knowledge skills [3]. Social networking sites also conduct online examination which play an important role to enhance the students' knowledge.

\begin{tabular}{|lr|}
\hline \multicolumn{2}{|c|}{ Purpose of Internet Usage } \\
\hline User & Percentage \\
\hline & \\
\hline Mail & 33 \\
\hline Surfing & 26.8 \\
\hline Chatting & 18.7 \\
\hline Social & 17 \\
\hline Networking & 4.5 \\
\hline Other \\
\hline & 100 \\
\hline Total & \\
\hline
\end{tabular}

Fig. usage of social media on education[7]

In the above table 1 it is clear that, internet usage for the respondents was for mailing and surfing the net with $33 \%$ and $26 \%$ respectively. Mainly two traditional reasons for using Internet i.e. Mailing and Surfing. In India, social networking sites are growing fast to gain popularity but it haven't reached the expectation of global scenario. Just $17 \%$ reported social networking sites as their principle reason for Internet usage. Alternating reactions were downloading internet content, purchasing online goods, studying and reading e-books [7] 


\begin{tabular}{|lr|}
\hline \multicolumn{2}{|l|}{ Membership in social networking sites } \\
\hline Member of SNS & Percentage \\
\hline & \\
\hline Yes & 95.7 \\
\hline & 4.3 \\
\hline No & \\
\hline & 100 \\
\hline Total
\end{tabular}

Fig. Membership in social networking sites for education [7]

Among the Indian youth $95.7 \%$ of the members are connected with the social media. These figures are increasing day by day. Whereas only $4.3 \%$ of members are not connected with the social media [7].

\subsubsection{Positive Effect of Social Media on Education}

- Social media gives a way to the students to effectively reach each other in regards to class ventures, bunch assignments or for help on homework assignments [12].

- Many of the students who do not take an interest consistently in class might feel that they can express their thoughts easily on social media [12].

- Teachers may post on social media about class activities, school events, homework assignments which will be very useful to them [12].

- It is seen that social media marketing has been emerging in career option. Social media marketing prepares young workers to become successful marketers.

- The access of social media provides the opportunity for educators to teach good digital citizenship and the use of Internet for productivity [13].

\subsubsection{Negative effect of Social Media on Education}

- The first concern about the negative effect comes to mind is the kind of distraction to the students present in the class. As teachers were not able to recognize who is paying attention in the classroom [12].

- One of the biggest breakdown of social media in education is the privacy issues like posting personal information on online sites.

- In some of the scenario there were many in appropriate information posted which may lead the students to the wrong side.

- Because of social media students lose their ability to engage themselves for face to face communication.

- Many of the bloggers and writers posts wrong information on social sites which leads the education system to failure.

\subsection{Impact of Social Media on Business}

Social media is the new buzz area in marketing that includes business, organizations and brands which helps to create news, make friends, make connections and make followers. Business use social media to enhance an organization's performance in various ways such as to accomplish business objectives, increasing annual sales of the organization. Social media provides the benefit as a communication platform that facilitates two way communication between a company and their stock holders [6]. Business can be promoted through various social networking sites. Many of the organization promotes their business by giving advertisement on the social media in order to attract maximum users or customers. Customers can connect and interact with business on a more personal level by using social media. If an organization has established a brand, social media may help this organization to develop the existing brand and give the business a voice. With the help of social media organization can make their strategy to promote their organization.

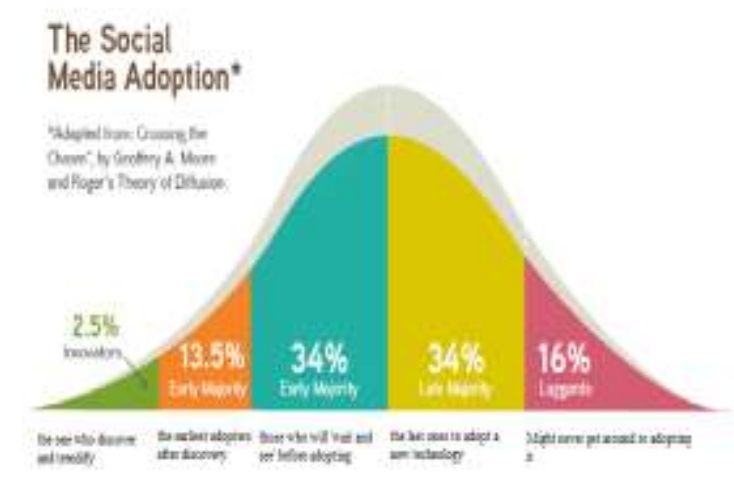

Fig: Social media adaptation [8]

Social media used in various business functions. Some of them are:

Marketing- Marketing is one of the most important and common use of social media in business. It works because today every brand has a target section of online audience.

HR-Is great for identifying and engaging the talent directly.HR helps company to showcase their employee benefits and culture of the company to outside world.

Creative- it share enables art, copy and design teams to invent new ideas which is useful for company to achieve goal.

Operations/strategy- Many of the sites like LinkedIn helps the business by connecting with the experts who can share some strategic plans.

Business Development- Professional networking sites can be used to connect with the clients. 


\subsubsection{Positive Effect of Social Media on Business}

- Social Media helps to better understand their audience by their likes and dislikes [14].

- It helps the business for promotional activities.

- Social networking sites helps to make new customers by providing useful facilities.

- Helps to enhance market insight and stretch out beyond your rivals with online networking [14].

- It also helps to increase awareness among brands and reach with little to no budget [14].

\subsubsection{Negative Effect of Social Media on Business}

- In business filed social media is not entirely risk free because many of the fans and followers are free to post their opinion on a particular organization, the negative comment can lead the organization to failure.

- Many of the large organization have fallen victim to the hackers.

- The wrong online brand strategy can doom a company, and put at a huge viral social disadvantage[15].

- Getting involved with Social Media is very time consuming. As an organization you should assign a person to always bolster your pages and profile with significant substance [15].

- Most companies have difficulty measuring the results of social media advertising.

\subsection{Impact of Social Media on Society}

As we all are aware of social media that has an enormous impact on our society[7].Many of the social media sites are most popular on the web. Some social media sites have transformed the way where people communicate and socialize on the web. Social networking sites render the opportunity for people to reconnect with their old friends, colleagues and mates. It also helps people to make new friends, share content, pictures, audios, videos amongst them. Social media also changes the life style of a society.

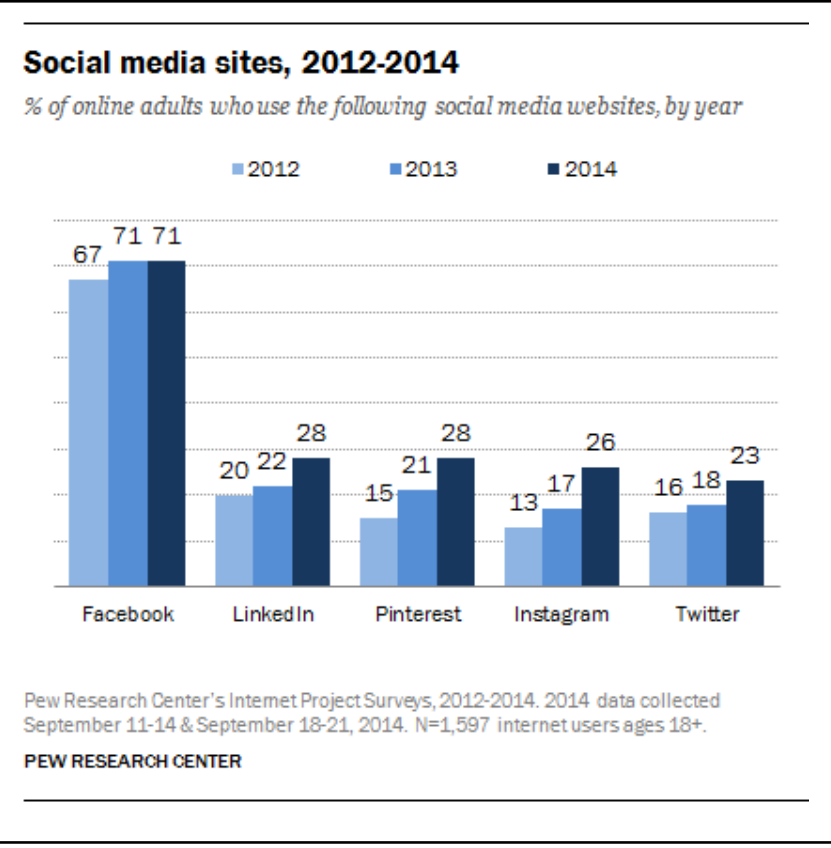

Fig: Usage of social media in the society [9]

According to the survey conducted by the Pew Research Center, in September 2014, 52\% of the online adults use two or more social media sites. More than half of the online adults of age 65 and above use $60 \%$ of Facebook which represents $31 \%$ of all seniors. Half of the internet-using young adult's ages 18-29 use 53\% Instagram and half of the Instagram users $(49 \%)$ use the site daily. The share of internet users with college education using LinkedIn reached $50 \% .42 \%$ of online women now use the platform, compared with $13 \%$ of online men [9].

\subsubsection{Positive Effects of Social Media on Society}

- Social Media helps to meet people they may not have met outside the social media forums.

- It also helps to share ideas beyond the geographical boundaries.

- It provides open opportunity for all writers and bloggers to connect with their clients.

- Another positive effect of social networking sites is it unite people on a huge platform for the achievement of specific goals. This brings positive change in the society.

- Social media provides awareness among society like campaigns, advertisement articles, promotions which helps the society to be up to date with the current information. 


\subsubsection{Negative Effects of Social Media on Society}

- One of the negative effect of social media is that it make people addicted. People spend lots of time in social networking sites which can divert the concentration and focus from the particular task.

- Social media can easily effect the kids, the reason is sometimes people shares photos, videos on media that contain violence and negative things which can affect the behavior of kids or teenagers.

- It also abuses the society by invading on people's privacy.

- Social lies like family ones also weaken as people spend more time connecting to new people.

- Some people uses their images or videos in social sites that can encourage others to use it false fully.

\subsection{Impact of Social Media on Youngsters}

Nowadays social media has become a new set of cool tools for involving young peoples. Many young people's day to day life are woven by the social media Youngsters are in conversation and communication with their friends and groups by using different media and devices every day [16]. In past years it was seen that youngsters are in touch with only friends and their groups in schools and colleges. But nowadays youngsters are in contact not only with known friends but also with unknown people through social networking sites, instant messenging etc. [16]. According to BBC news research of 2013 they discuss that $67 \%$ Facebook users are very common and well known social media portal consist of the youth and students, so these praise the fact that the youth and student have more focus and relation [11].Throughout the country teenagers frequently use the web, mobile phones, online games to communicate and gather information with each other. As per the survey in California the below table shows that how social media impacts the behavioral health of California's adults [17].

\begin{tabular}{|l|l|l|}
\hline TYPE & EXAMPLE & $\begin{array}{l}\text { \%TEENS WHO USE } \\
\text { SOCIAL MEDIA } \\
\text { NATIONALLY }\end{array}$ \\
\hline $\begin{array}{l}\text { Text } \\
\text { Messenging }\end{array}$ & $\begin{array}{l}\text { Cellphone } \\
\text { feature }\end{array}$ & $\begin{array}{l}75 \% \text { of all teens own } \\
\text { a cell phone, } \\
88 \% \text { of cell phone- } \\
\text { owning teens text, } \\
72 \% \text { of all teens use } \\
\text { text messaging }\end{array}$ \\
\hline $\begin{array}{l}\text { Social } \\
\text { networking } \\
\text { sites }\end{array}$ & $\begin{array}{l}\text { Fycebook, } \\
\text { MySpace }\end{array}$ & $\begin{array}{l}73 \% \text { of online teens } \\
\text { have used a social } \\
\text { networking site }\end{array}$ \\
\hline $\begin{array}{l}\text { Online video } \\
\text { sites }\end{array}$ & Youtube.com & $\begin{array}{l}63 \% \text { of online teens } \\
\text { watch online videos }\end{array}$ \\
\hline $\begin{array}{l}\text { Online } \\
\text { gaming }\end{array}$ & SecondLife.com & $\begin{array}{l}61 \% \text { of online youth } \\
\text { play games online, } \\
\text { including } \\
\text { multiplayer online } \\
\text { games }\end{array}$ \\
\hline $\begin{array}{l}\text { Blogging with } \\
\text { in social } \\
\text { sites }\end{array}$ & $\begin{array}{l}\text { Facebook or } \\
\text { MySpace } \\
\text { feature }\end{array}$ & $\begin{array}{l}52 \% \text { of online teens } \\
\text { have commented on } \\
\text { a blog }\end{array}$ \\
\hline
\end{tabular}

Fig: usage of social media by youth [17]

\subsubsection{Positive Effects of Social Media on Youngsters}

- Social media helps youngsters to stay connected with each other.

- Useful information can be exchanged over social networking sites.

- Social networking sites can allow teens to find support online that they may lack in traditional relationships, especially for teens [17].

- In a Critical Development period youngsters also go for social networking sites for advice and information.

- Youngsters can look to social media for getting the answers related to their career objectives. 


\subsubsection{Negative Effects of Social Media on Youngsters}

- Today it's not clear that who the "strangers" are especially in the field of social media.

- $\quad$ Kidnapping, murder, robbery can be easily done by sharing details on social media.

- There are many cases registered in police station where adults target young children and lure them into meeting them.

- Mostly youngsters waste lots of time on social sites like chatting which also effects their health.

- Some useless blogs influence youth extremely that they become violent and can take some inappropriate actions.

\section{CONCLUSION}

As the technology is growing the social media has become the routine for each and every person, peoples are seen addicted with these technology every day. With different fields its impact is different on people. Social media has increased the quality and rate of collaboration for students. Business uses social media to enhance an organization's performance in various ways such as to accomplish business objectives, increasing annual sales of the organization. Youngsters are seen in contact with these media daily .Social media has various merits but it also has some demerits which affect people negatively. False information can lead the education system to failure, in an organization wrong advertisement will affect the productivity, social media can abuse the society by invading on people's privacy, some useless blogs can influence youth that can become violent and can take some inappropriate actions. Use of social media is beneficial but should be used in a limited way without getting addicted.

\section{REFERENCES}

[1] Aveseh Asough, SOCIAL MEDIA AND ETHICS - The Impact of Social Media on Journalism Ethics, Center for International Media Ethics (CIME),December 2012

[2] https://en.wikipedia.org/wiki.Social_media\#References

[3] Gitanjali Kalia Chitkara University, Punjab, A Research Paper on Social media:An Innovative Educational Tool, Issues and Ideas in Education Vol. 1 March 2013 pp. 43-50

[4] www.edudemic.com/social-media-education/
[5] Waqas Tariq, Madiha Mehboob, M. Asfandyar Khan FaseeUllah, The Impact of Social Media and Social Networks on Education and Students of Pakistan, IJCSI International Journal of Computer Science Issues, Vol. 9, Issue 4, No 3, July 2012

[6] http://www.business2community.com/social-media/

[7] Dr. M. Neelamalar \& Ms. P. Chitra,Dept. of Media Sciences, Anna University Chennai, India, New media and society: A Study on the impact of socialnetworking sites on indian youth, Estudos em Comunicac, ao no6, 125-145 Dezembro de 2009

[8] Abhimanyu Shankhdhar, JIMS / Social media and businss /

[9] http://www.pewinternet.org/2015/01/09/social-media-update2014/pi_2015-01-09_social-media_01/

[10] hubpages.com/technology/effects-of-social-media-on-our-youth

[11] Ghulam Shabir,Yousef Mohammed Yousef Hameed,Ghulam Safdar, Syed Mohammed Farooq Shah Gilani,"the impact of social media on Youth: A case study of Bahawalpur City, Asian Journal of Social Sciences \& Humanities Vol. 3(4) November 2014

[12] https://www.schooliseasy.com/2014/02/social-media-in-theclassroom/

[13] http://www.edudemic.com/how-students-benefit-from-usingsocialmedia/

[14] http://blog.hootsuite.com/social-media-for-business/

[15] http://www.automatedbuildings.com/news/sep11/columns/1108 26030404mandrusiak.html

[16] http://www.practicalparticipation.co.uk/yes/what/what_does_it change

[17] Impact of Social Media on Adolescent Behavioral Health in California,

Source: (Lenhart, 2010) except for Online video sites (Nielsen, 2009) \& Online gaming (McAfee, 2010) 